Please cite only the published version: Journal of Value Inquiry online first 2017, DOI 10.1007/s10790-017-9598-5

\title{
Morality and Prudence: A Case for Substantial Overlap and Limited Conflict
}

\section{Topic and Approach}

It is virtually impossible to say anything substantial about how morality and prudence relate to one another unless we make assumptions about their content. In what follows, I will make use of a minimal definition, according to which prudence concerns the rational pursuit of personal interest and happiness. In this connection, I use happiness as an evaluative term, as something desirable that makes life as a whole good, better or successful. ${ }^{1}$ However, the nature of happiness is only discussed insofar as it is directly relevant for understanding how prudence relates to morality. As far as possible, I want to be neutral about how happiness, self-interest, and morality are to be defined, since defining these terms is beyond the scope of this article and any definition can favor certain theories while excluding others, which would make the discussion unnecessarily narrow in scope. ${ }^{2}$ Nevertheless, I distinguish between the following interpretations of morality (or moral virtue and moral rationality):

(1) That we give significant weight to the interests of others (independently of prudential concerns);

(2) that the interests of others weigh at least as much as our own;

(3) that full impartiality is required (e.g. the universalization of maxims). ${ }^{3}$

In this paper I discuss problems that arise if we accept (2) or (3), particularly the dualism of practical reason and Robert Adams' demoralization thesis. These problems do not arise if we give so little weight to the interests of others that it is moral to sacrifice them if prudential interests are undermined (a weak form of 1). The argument I develop is largely consistent with several different frameworks in normative ethics (e.g. virtue-ethics, Kantianism). In what follows I proceed via negativa by discussing how not to conceive of morality and prudence. I then argue for an intermediary position, in which morality and prudence substantially overlap. 
This position neither implies nor precludes eudaimonism; it is compatible with valuing morality for its own sake, and allows for seeing moral reasons as overriding and categorical. ${ }^{4}$ The argument I develop rests on the assumption that we rightly tend to take strong interests in both morality and prudence, and that the two need not be identical. I assume that morality is binding on us and that moral life is possible, and try to articulate presuppositions, or conditions of possibility, for moral life. ${ }^{5}$ By this, I aim to articulate non-exhaustive conditions to which we are (at least implicitly) committed insofar as we are moral and rational.

The relation between morality and prudence is central to contemporary debates on ethical egoism, eudaimonism, the authority of morality, practical rationality, normative pluralism, incommensurability, incomparability, as well as discussions of providence and moral order. ${ }^{6}$ How morality and prudence relate can be seen as a theoretical and empirical question which concerns our knowledge of the world. However, it might also be seen as a question that concerns the ethics of belief, or what we should believe about morality and prudence if we cannot settle the issue with adequate theoretical knowledge. ${ }^{7}$

\section{The Idea of a Moral Order}

The first view says that morality coincides fully with prudence and immorality with imprudence. This view is often interpreted causally in the sense that morality causes happiness and vice causes unhappiness (another variant states that morality and prudence are identical). ${ }^{8}$ Although this view seems appealing, meritocratic and egalitarian, there are also serious problems with it.

It seems clear that we do not experience human history as such a moral order. Rather, some good agents seem unhappy (or imprudent), while some happy (or prudent) agents do not seem good. In particular, the existence of injustice and tragedies indicates that this is the case. ${ }^{9}$ Aristotle writes: "Those who assert that the person broken on the wheel and falling into 
great misfortunes is happy, if only he is good, are [...] talking nonsense." $" 10$ The idea of a moral order simply explains away coincidences, injustices and tragedies by confusing natural evil with moral evil and natural disasters with moral disasters. ${ }^{11}$ A full overlap between morality and prudence would legitimize everything that happens in the history of humanity. The happy and prudent are justified, since they are seen as morally good, while the unhappy and imprudent are demonized, since they are taken to be vicious, immoral or evil. Reality is seen as legitimate and rational, since it expresses moral and prudential rationality. There is no point in trying to make the world a better place by making society more just or meritocratic, since it is perfect already.

This view can also be criticized for not leaving enough room for moral action and moral development if it is possible to attain complete and comprehensive happiness in this life (as assumed by some eudaimonists). Insofar as happiness is comprehensive, it will put an end to our desires; we will neither lack anything, nor desire nor strive for anything, if we are perfectly happy. ${ }^{12}$ An operative moral order would then simply undermine the very need for moral action. Only immoral and amoral agents would be able to act and strive (although they would never attain happiness). It therefore seems like we need some minimal unhappiness or imperfection in order to act, strive and develop morally. ${ }^{13}$ Otherwise, the result seems to be a contemplative and boring state for good agents. ${ }^{14}$

Finally, a moral order threatens moral motivation. As Jens Timmermann writes, if a being: cannot experience any tension between prudence and the demands of morality it cannot be moved by, or take a pure interest in, the moral law as such $[\ldots]$ We need the "subjective antagonism" $[\ldots]$ of moral law and inclination for the law to affect our subjectivity. When we perceive that selfishness and moral judgement conflict, we realize for the first time that we are not enthralled by inclination, and that there is something within us that is active 
and radically free. This inspires respect, which in turn enables us to act independently of self-regarding considerations. ${ }^{15}$

This Kantian argument can perhaps be adopted by eudaimonists, since the virtues involve other-regarding concerns that cannot be reduced to a self-regarding striving for happiness. ${ }^{16}$ The virtue of justice, notably, should not merely serve my happiness but give to each what they deserve. Virtue must therefore be valued for its own sake, not just because it serves personal interest or happiness. However, this seems virtually impossible if virtue and prudence necessarily coincide (or are coextensive), since we would then confuse the instrumental role of virtue with its constitutive (intrinsic) role. Thus, any conflict between virtue and prudence has the advantage of illustrating that virtue should be sought for its own sake. ${ }^{17}$ It is morally preferable if the moral order is transcendent, because we can only act morally in an imperfect world, in which morality and prudence diverge, a world in which we cannot always know if morality serves personal interest or happiness. ${ }^{18}$

The idea of a moral order is deeply problematic if it is identified fully with human history. Overall, these problems suffice for rejecting full overlap between morality and prudence. This indicates that the tension between morality and prudence is systematic, representing a fundamental - if minimal - structural feature of human rationality. Practical rationality presupposes at least two heterogeneous values, goods or reasons, represented by morality and prudence. ${ }^{19}$ Without some divergence between morality and prudence, the position is vulnerable to the problems identified above (e.g., demonizing the unhappy). Nevertheless, this view does not rule out the claim that virtuous agents are happier than vicious agents and that the virtuous therefore handle adversity better than others. However, it is incompatible with the Stoic claim that the virtuous are completely happy, invulnerable and self-sufficient, like unconquerable fortresses ${ }^{20}$ Even if the virtuous harmonize morality and 
prudence to a greater extent than the vicious do, this does not guarantee a complete overlap between the two or even that moral perfection is humanly possible (as assumed by the Stoics).

The relation between morality and prudence even seems to vary somewhat across societies. More specifically, societies that allow immoral practices such as slavery and torture involve a clearer conflict between morality and prudence than societies that prohibit these practices. $^{21}$ The idea of a moral order is more convincing and appealing if it is interpreted as an ideal world that we may hope to progress towards in the future. In other words, it can be considered as an idea that we should strive towards by acting morally and politically in ways that minimize conflicts between morality and prudence (e.g. by organizing society in such a way that it pays off to be law-abiding, hard-working and eco-friendly). John Silber argues, for instance, that we work towards the idea of a moral order by promoting proportionality between desert and happiness, in many different activities such as grading of papers, serving on juries, and rearing children. ${ }^{22}$ Still, moral agency would be undermined if the moral order were completely realized at some point in human history. A complete realization of the moral order must therefore - if possible - be situated not in history but outside it. The idea of a moral order can then be interpreted as a regulative idea that we should promote and approximate, although the idea itself is transcendent.

\section{Morality and Prudence Always Clash}

According to the second view, morality coincides completely with imprudence, while immorality coincides completely with prudence. ${ }^{23}$ This avoids some of the problems associated with the previous position but it introduces new problems. First, this position is very difficult to support empirically, even if we admit that cases of injustice and tragedy are all too common. ${ }^{24}$ Conflicts between morality and prudence seem to represent local, contingent phenomena, rather than anything universal or inevitable. Psychological studies 
even indicate that some moral behavior, such as volunteer work or kindness, does in fact makes us happier in various respects. Empirical research points to a positive connection between morality and prudence, irrespective of the theory of happiness we favor. ${ }^{25}$

Second, this pessimistic view rules out, or tries to explain away, coincidences or contingencies because prudence is taken to coincide perfectly with immorality. This position has the same problem as the previous position, except that the relations between (i) morality and prudence, and between (ii) moral and natural evil, are inverted. The previous position legitimizes and favors the happy, successful and fortunate, whereas this position legitimizes and favors the unhappy, imprudent and miserable.

Third, moral virtue seems to require that we enjoy being moral. We must, at least, gladly be moral rather than reluctantly. ${ }^{26}$ It then seems impossible to become totally unhappy, or lose all personal interests, by being moral; any conflict between morality and prudence must be partial instead of total. Finally, this pessimistic position involves splitting our practical rationality into two separate and incompatible normative domains, which are both necessary. The result is a (global) dualism of practical reason that demands both that we seek personal interest and happiness and that we sacrifice it for the sake of morality. ${ }^{27}$ It would consequently be simultaneously true and untrue that we ought to seek happiness and selfinterest, just like it would be both true and untrue that we ought to be moral. ${ }^{28}$ When both morality and prudence are necessary, and cannot be reconciled, we get a dualism that prevents a higher standpoint from which morality and prudence can be mediated. This dualism leads to a normative pluralism, in which morality and prudence are incommensurable normative domains. ${ }^{29}$ What is morally right differs from what is prudentially right; moreover, there is no higher standpoint which can overcome this dualism and prescribe what is best all-thingsconsidered. There is no single overarching norm of rationality that prescribes action, but only two incompatible normative domains which are both authoritative. To change perspective 
from morality to prudence, or vice versa, involves a Gestalt switch, as it is impossible to find common ground and to take on both perspectives simultaneously. Practical reason is at odds with itself and the conflict cannot be settled rationally with arguments. The result is either paralysis or that non-rational impulses become decisive for moral action, something which undermines the rational authority of morality. ${ }^{30}$

The dualism of practical reason is weakened but not eliminated if we insist, in a Kantian manner, that morality has priority over prudence. For Kant admits that conflicts between morality and prudence involve a dilemma. The first horn of the dilemma takes the form of prioritizing prudence over morality. Kant criticizes this position for "throw[ing] away and despis[ing] the law of virtue" and "giv[ing] way to vices." 31 The second horn involves holding morality to be self-sufficient, either by reducing prudence to morality or by denying that prudence is needed. Kant describes the former position as that of a Stoic and the latter as that of a virtuous fool or dreamer (Phantast). The Stoic strains "the moral capacity of the human being [...] far beyond all the limits of his nature"; he assumes "something that contradicts all cognition of the human being" by raising "himself above the animal nature of the human being" and claiming himself to be "sufficient to himself." 32 The Stoic line of reasoning fails since the moral agent is not only a free rational being, but also a finite natural and sensuous being with needs and desires. The Stoic thereby lacks something to satisfy his vital needs and something to mediate between moral freedom and nature. As a result, he leaves unresolved whether or not everything necessary for being virtuous will be provided by nature. ${ }^{33}$ Similarly, he who denies the importance of prudence is a fool or a Phantast, since he denies his own nature and "expect[s] no consequences which are worthy of" his conduct. ${ }^{34}$ Kant concludes that, without belief in a moral order, the result is an "unstable condition" in which we continuously fall "from hope into doubt and mistrust."35 
The important point is that a serious perceived or experienced conflict between morality and prudence leads to demoralization, in the sense of weakened or deteriorated moral motivation. I will refer to this as the demoralization thesis, a thesis put forward by Robert Adams, which claims that a serious, inescapable conflict between morality and prudence tends to result in demoralization. Even if some agents manage to sacrifice their happiness or self-interest for the sake of morality, it still seems somewhat unrealistic and overly demanding to consider it a general demand to renounce personal interests and happiness. At least, this seems to be the case either if personal interests or happiness are objective goods which benefit us (whether we recognize it or not), or if they are something we psychologically desire or strive for. ${ }^{36}$ A strong conflict between morality and prudence is then likely to lead to demoralization as a general tendency. ${ }^{37}$ Psychological literature offers some support for the demoralization thesis in cases in which we sacrifice virtually everything - including happiness - to the end of survival. Concentration camp prisoners, notably, are reported to have been almost universally demoralized as a result of miserable living conditions. ${ }^{38}$

This is not just a psychological problem, but also a problem concerning the rational authority of morality. Do we have most reason to prioritize morality or prudence, given a strong and inevitable conflict between the two $?^{39}$ Is it rational, all-things-considered, for an individual to sacrifice happiness and self-interest? Quietists take morality to require total selfforgetfulness and renunciation of all self-interested motivation. They think that virtue is incompatible with "any though of the benefits one gains from" being virtuous (notably personal happiness). ${ }^{40}$ However, this position seems too extreme. Consider promoting the happiness and interests of others in a world in which morality and prudence are incompatible. Although it seems moral to promote others' happiness and interests, it would nevertheless undermine their own morality. The absurd implication is that my morality is incompatible with their morality. The absurdity can be avoided either by rejecting this pessimistic position 
or by rejecting that it is moral to promote others' happiness and interests. The former is clearly more reasonable than the latter. It then appears that we have stronger reasons for rejecting the pessimistic position than the previous position (and the next one).

\section{The World as a Moral Lottery}

The idea of a moral lottery implies that the relation between morality and prudence is completely contingent and arbitrary. ${ }^{41}$ On this view, personal interests and happiness depend on good fortune, whereas morality depends on human freedom. This is an anti-egalitarian position, according to which some are lucky and others unlucky. The position is modern insofar as nature is separated sharply from morality; natural evil is not moral evil, and natural laws are not moral laws. Nature is entirely amoral and indifferent towards morality.

This position tends to reduce moral agency to inner actions that only concern volition, motivation and dispositions. This is similar to a dualistic, Kantian position in which the good will is morally valuable even if hindered by disfavors of fortune. ${ }^{42}$ However, it seems deeply problematic if moral agency is totally powerless and if moral actions cannot make any difference whatsoever as far as happiness and self-interest is concerned. Psychological studies tend to undermine this dualistic picture. ${ }^{43}$ And not even Kant would say that moral action is entirely disconnected from, or without effect in, nature. Although some moral actions may fail to realize their intended goals (because of mishaps or other contingent circumstances outside of our control), this does not imply that moral agency generally fails. For it seems like coincidences, which prevent the realization of our moral intentions and plans, represent local phenomena that are contingent rather than anything universal and necessary. Moreover, even if the relation between morality and prudence is contingent, it need not be completely arbitrary or preclude some kind of causal connection, regularity or correlation. 
Viewing the world as a lottery, as this position does, makes practical reason a hostage to fortune. Even if we were to attain both virtue and happiness, happiness would still not result from our striving, but from coincidences beyond our control. And why should we strive for something that we can neither control nor influence, since the outcome is entirely in the hands of fortune? This position makes us suffering victims rather than rational agents who influence our own situation in any predictable manner. It undermines our all-thingsconsidered rationality and prudential rationality. Practical rationality is split into two separate domains, morality and prudence, which cannot be coordinated in any predicable way. Planning, deliberation, and anticipation of outcomes becomes very difficult and moral agency is threatened by demoralization and the dualism of practical reason to various degrees at the local level.

\section{The Need for an Intermediary Position}

It is clear that the three positions we have discussed are all deeply problematic and that an intermediary position would be more promising. However, it seems much less clear exactly which intermediary position would be best. In the following, I will consider a position that is an intermediary between the first and the third positions, since I see the second position as the least promising. I will then assume that there are two different tendencies at work: There is a significant overlap or correlation between morality and prudence, but there are also contingencies and conflict that hinders a total overlap, or identity, of the two.

First, as previously mentioned, psychological studies indicate considerable overlap between moral behavior and prudence. As Valerie Tiberius summarizes:

Psychologists do not study "being moral" - this is too vague and broad. But psychologists do study particular moral behaviors, such as volunteer work, kindness and helping. [...] 
this research shows [that] we have some [prudential] reasons to do some moral things.

[...] doing helpful things for other people does cause us to be happier in various respects ${ }^{44}$

Not only do helpfulness contribute to happiness but being happy also "tends to make people more sociable and concerned about others". ${ }^{45}$ Another (related) reason for assuming a significant overlap between morality and prudence is that we tend to impose social sanctions on those who act immorally and to support those who act morally. Yet another reason is that we tend to experience shame, guilt, and anguish when doing wrong; we experience negative self-assessments that weaken self-respect and happiness. Finally, we tend to enjoy being moral and to promote the happiness of others, something that could both come from feelings of sympathy as well as having personal commitments and projects that include others' happiness and interests. ${ }^{46}$ Indeed, genuine moral virtue seems to require that we enjoy being moral. At least, it requires that we are moral willingly and gladly rather than reluctantly. ${ }^{47}$ Mathias Sagdahl writes:

[I]t has been argued that those exhibiting traits or vices such as callousness or those who lack the moral virtues are unable to form true and faithful interpersonal relationships, such as true friendship and love. These relationships, it is argued, require a certain level of empathy and sympathy with other people, and to see people as valuable in noninstrumental ways. The callous person lacks these sentiments and so is unable to form true relationships. In addition, they are unable to show their true selves to the world, but must act in secret and so cannot live sincerely. Living sincerely without hiding and pretence might be seen as a good in itself, but it might also be connected with inner states. Plato famously appealed to the "psychic harmony" enjoyed by the morally virtuous person, and which is unavailable to the vicious person. ${ }^{48}$ 
In The Sickness unto Death, Kierkegaard argues that vicious and sinful agents not only lack psychic harmony, but also that they are in despair and deceive themselves, whether they recognize it or not. ${ }^{49}$ John Lemos develops an alternative approach. He argues that those who only pretend to be moral are likely to suffer social sanctions and ostracism:

[T] he cunning, self-serving egoist who appears virtuous is always more likely to suffer as a consequence of his being such than is the man of virtue. Usually such selfish types acting under the guise of virtue are found out, and when this happens they are just as open to the misfortunes of anyone else who is caught in wrongdoing. ${ }^{50}$

Lemos' approach leads to a new problem (a problem not associated with the theories of psychic harmony and despair), namely that morality seems to be dependent on a society that may be corrupted by, for instance, sexism, racism or slavery. Lemos replies to this objection by arguing that prudence requires the development of "intellectual skills," "knowledge, and critical thinking capacities" as a means of dealing with "changing social, economic, environmental, etc. conditions in life"; without such skills, knowledge and capacities, we are unlikely to become independent members of society with good chances of "living a happy and fulfilling life". ${ }^{51}$ However, it is exactly this knowledge, and these skills and capacities, that give us insight into not only what is useful to us but also whether our morality is corrupted or not. It is exactly here that the critical potential lies. Imagine that you find out that the virtues you have inherited and appropriated involve a clear element of corruption. This insight is so disturbing that it will force you to choose between moral reform and (continued) corruption. However, an active choice of moral corruption represents a bad option for someone who is already committed towards morality, since it probably involves an element of self-deception 
in order to repress the awareness of being corrupted. Prudence requires knowledge, skills and capacities that would prompt you to avoid self-deception, since self-deception is likely to breed unhappiness in the long-run by masking your true character and abilities, so that you misunderstand yourself and how you function in society. Self-deception therefore greatly increases the risk of mistakes and failures that seriously threaten long-term happiness. If this is right, the conclusion would follow that you are unlikely to be happy unless you are also moral. ${ }^{52}$ Lemos' view is in line with eudaimonists, who plausibly argue that virtuous agents tend to handle varying situations better than vicious agents do. This is not just a point about the prudential advantages of being moral; it is also a point about how virtues involve dispositions, practical rationality and emotions, which help us cope with reality in an intelligent and skillful manner. ${ }^{53}$

A different strategy for supporting overlap and compatibility between prudence and morality would be to make use of a heuristic notion of progress, as Kant does in the philosophy of history. This approach relies on a regulative notion of teleological progress used as a guiding principle for making sense of human history. History is interpreted teleologically as a coherent system that progresses, rather than as a mere aggregate of actions. More specifically, Kant assumes a regulative notion of historical progress towards legality, morality, and the moral order (the highest good), which seems to fit the empirical data to a considerable extent. At least, this seems to hold for the development towards democracy, human rights, juridification, education, enlightenment and technological-scientific progress. ${ }^{54}$ For example, the development of the rule of law and representative government is assumed to "prepare the way for morality by making us less partial towards our own interest, disciplining our emotions, and instilling less violent behavior patterns". ${ }^{55}$ This teleological interpretation of history is developed by Kant in order to make sense of history and to portray moral and prudential progress not just as possible but also feasible (the practical use of history matters 
more than theoretical knowledge in this connection). It offers encouragement by providing a sense of coherence and purpose to human striving that can prevent demoralization and despair. Instead of postulating actual progress towards a moral order, Kant argues that such progress is possible and that there is room for hope. The upshot is that giving up on hope would be premature, since we cannot be absolutely sure that the world prevents us from progressing towards the moral order (as a regulative idea that transcends experience). ${ }^{56}$ In different ways, these various considerations all support an intermediary position that involves a substantial overlap and considerable compatibility between morality and prudence. This intermediate position allows historical progress towards a moral order and prevents injustice and contingencies from completely undermining moral agency and practical reason. As a result, it largely avoids the problems associated with the previous positions (in Sections 2-4). More specifically, it makes room for moral motivation and moral development; and it avoids the worry that moral agency is undermined by arbitrariness, demoralization and an unresolvable dualism of practical reason. The intermediate position therefore seems to provide more room, or better conditions, for practical reason and moral agency.

However, it cannot remove contingencies, injustice, suffering or death, particularly not at the local and individual levels. Practical reason and moral agency are secured at the collective, historical level, rather than at the individual level. For some individuals will suffer more than others because of bad luck, tragedies and injustice (something that increases the chances of demoralization and paralysis). Moreover, the Kantian approach to history involves general, progressive tendencies that may not help individuals, particularly not individuals in the past. The victims of the Third Reich, for instance, are not helped much by European PostWar progress. In other words, individual agents may be threatened by injustice, suffering and death, although this need not undermine practical reason and the moral community in general (unless a global catastrophe results in human extinction). It is therefore clear that these 
problems are greater at the individual level than at the collective, historical level. These considerations support substantial overlap and rough compatibility between morality and prudence in many rather than all cases.

We should not rule out limited conflict between morality and prudence. Daniel Haybron gives an example of a situation in which one has to choose between adopting a child with autism and cerebral palsy, and letting the child live in an institution that provides tolerable but impersonal care. ${ }^{57}$ Adopting the child involves moral excellence at the price of a significant sacrifice of social activities, career opportunities, hobbies and personal economy. Another case of conflict between morality and prudence would be someone who either has to go along with racism, sexism and corruption or to protest against it, at the price of losing his job and social standing (at least temporally). In this case, it is the virtuous agent who suffers social and economic sanctions, although he is also likely to receive some support from sympathizers and oppressed groups. ${ }^{58}$ In cases like these, it seems that we can have sufficient moral reasons for sacrificing considerable prudential interests. Such moral sacrifices are incompatible both with positions that prioritize prudence over morality and with ethical egoism (the view that prudence is necessary and sufficient for morality) ${ }^{59}$ Still, we need not accept quietism, which demands a general sacrifice of personal interests and happiness. Nor do we need to accept anti-eudaimonism, the (closely related) view that proper regard for virtue rules out that virtue is "a part of, or a means to, our happiness" (or self-interest) ${ }^{60}$

Instead, we can accept either non-eudaimonism or a form of eudaimonism that allows moral sacrifices. Non-eudaimonists (e.g. Kant) think that morality can be justified independently of prudence. They hold (in the words of Terence Irwin) that "we have sufficient reason to pursue virtue above all other goods or advantages even if it conflicts with happiness [and self-interest] or it does not affect it either way" (although prudence plays an important secondary role, since it can provide practical reasons and a second defense of 
morality). ${ }^{61}$ Eudaimonists, by contrast, justify morality by appealing directly to prudence, seeing virtue as (at least partially) constitutive and necessary for happiness. Still, some eudaimonists do not just allow but also require that we prioritize morality over prudence at the level of particular actions and "local deliberations and motives" (as opposed to the global level of life as a whole). ${ }^{62}$ For it is more plausible to assume that we can have good reasons for sacrificing personal interests and happiness in particular situations, and to some degree, than to assume that prudence must be sacrificed totally. Sacrificing prudence to a maximal degree seems not only unacceptable prudentially, but also morally problematic, unless Adams' demoralization thesis is wrong and quietism is right. At least, this seems to be the case if we want to avoid that morality becomes overly demanding, ascetic, elitist and unrealistic.

There may even exist situations in which it would be morally right to sacrifice our lives. ${ }^{63}$ Still, it seems unfortunate to believe that morality demands that all personal interest and happiness is sacrificed and that we consequently have to live a life without any wellbeing, self-interest or even contentment. It is difficult to see how we can function as rational agents without any understanding of prudence or self-interest. Even if we sacrifice much prudentially (as in the cases above), we still seem to need the idea of happiness or self-interest if we are to strive for a better life in any rational manner. The upshot is that moral sacrifices involve renouncing some measure of happiness rather than all happiness (or giving up some but not all personal interests). Being a parent, or adopting a child, typically reduces perceived happiness temporarily (the so-called parenting happiness gap). The preceding analysis clearly indicates that conflict between morality and prudence must be limited rather than total.

It should be kept in mind that the alternatives to living morally are typically bad prudentially (although moral sacrifices would then be avoided). There are three mutually exclusive options: (i) We have to live with a bad conscience and feel shame, guilt or anguish, 
something which undermines happiness and self-respect. (ii) We have to engage in selfdeception to hide our moral deficiency, something that is likely to breed unhappiness in the long run (as Lemos argued). (iii) We have to be egoistic amoralists who miss prudential advantages associated with being moral, especially when our amoralism is revealed (something that is not unlikely in the long run). For who would like to befriend, love or work with amoralists who are cunning or callous enough to hide their amoralism? And how likely is it that such amoralists are not exposed at some point; are they likely to be mistaken for virtuous friends, lovers, and colleagues who get substantial social support? Probably not. ${ }^{64}$ Merely in order to try to avoid social sanctions, such amoralists will have to live continuously in secret, in a tiresome and risky manner. They cannot be sincere and share openly with others without being exposed. Nor can they experience the enjoyment that moral virtue involves or truly participate in social practices and sustain relationships in non-instrumental ways. They are cut off from meaningful and significant activities and projects that involve intersubjective, non-instrumental moral standards of assessment. ${ }^{65}$

This indicates that it is prudentially counterproductive to be concerned only with one's own interests and happiness. ${ }^{66}$ At least, it is not clear that amoralists in general are likely to be better off prudentially than moral agents are. This is something we firmly seem to believe when we try to raise our children to become not just happy, but also moral. ${ }^{67} \mathrm{We}$ should in any case preclude the possibility that promoting the happiness and interests of others somehow undermines their morality, and we should rule out the possibility that our morality would be weakened if others promote our happiness and interests (see Section 3). This leads directly to the non-quietist assumption that morality and prudence must be thought of as being roughly compatible in general. Although we do not know whether prudence strictly requires virtue (as claimed by eudaimonists), it still seems, not only morally preferable, but probably also necessary for morality to be roughly compatible with prudence. Otherwise, it is not clear 
how our morality is compatible with others' morality or that we ought to promote their happiness and interests. Nor is it clear that demoralization (nor paralysis) can be avoided completely.

The demoralization thesis need not imply that it is a problem if vicious agents become happy or realize their interests (we need not be demoralized by this unless we accept instrumentalism about virtue). The problem is with moral agents who are unhappy (or lose their interests) to such an extent that their morality is weakened significantly. As a result, we do not need a moral order in which morality and prudence perfectly coincide. A weak order involving rough compatibility, and substantial overlap, between morality and prudence suffices to avoid demoralization and an unresolvable dualism of practical reason. ${ }^{68}$ But we may need stronger arguments to support a weak type of moral order that is operative in human history, if this overlap and compatibility is to cover all cases (including exceptional cases), so that demoralization and paralysis are avoided completely.

An additional way of supporting a closer connection between morality and prudence is to use a pragmatic argument. This type of argument typically starts from the assumption of certain objective moral facts, represented here by morality and prudence as necessary elements of practical reason. ${ }^{69}$ These moral facts are then thought to be best explained by assuming a type of moral order that involves (at least) significant overlap and rough compatibility between morality and prudence. Typically, one argues that we need to go beyond existing knowledge if we are to make sense of morality and prudence, and to avoid problems such as demoralization and an unresolvable dualism of practical reason. In order to make non-quietist morality possible, we then make constitutive assumptions about the moral structure of the world that transcend existing knowledge. We assume that practical reason is not doomed to failure due to demoralization or a stark dualism of practical reason, given a (weak) moral order that allows moral life by granting all the necessary conditions. More 
specifically, we must rule out the assumption that the relation between morality and prudence is generally arbitrary or negative. Instead, we must assume that morality is roughly compatible with prudence, even if it does not always appear so. Conflicts between morality and prudence are taken to be less fundamental and less persistent than they may appear, and thereby we avoid believing that morality is overly demanding and unrealistic.

Although this type of pragmatic argument is controversial, it can be rational, rather than irrational, if certain conditions are met. More specifically, the matter at hand must be urgent and of practical importance and the argument must not primarily serve wishes, inclinations or special interests. In addition, the argument must not conflict with existing knowledge. ${ }^{70}$ In this case, these conditions can probably be met if moral agents need some measure of happiness (or self-interest) in order to avoid demoralization and an unresolvable dualism of practical reason. Whether morality and prudence are realizable or not seems to represent a matter of utmost importance as far as practical rationality is concerned, since morality and prudence are not things we can dispense with altogether as humans. Furthermore, a moral order would, by its very nature, serve morality and general interests, instead of special interests, subjective wishes and inclinations. Finally, a weak form of moral order need not contradict existing knowledge. For we neither know the exact relation between morality and prudence in all cases, nor whether we ourselves are truly virtuous or whether all human lives are truly happy or prudentially rational. ${ }^{71}$ Exhaustive knowledge of how morality and prudence relate seems to require omniscience (knowing our hearts and minds and the whole of nature, both in the past and in the future). It is not sufficient to know about one's own case, since we should also promote the happiness and interests of others.

We should not assume that the virtuous are perfectly happy in this life. But neither should we assume that they become unhappy to such an extent that it inevitably results in demoralization or paralysis. ${ }^{72}$ We need therefore not accept strong forms of this argument, 
such as Kant's moral argument for the existence of God, which assumes that morality causes happiness. The pragmatic argument is only invoked to supplement the other arguments by assuming rough compatibility, not full overlap or identity, between morality and prudence in all cases. Even if it fails, we still have good, independent reasons for assuming considerable overlap and rough compatibility between morality and prudence in non-exceptional cases. ${ }^{73}$

1 Julia Annas claims that we have recovered the thought that happiness is an important ethical notion, although there is little agreement on what happiness is (Julia Annas, Intelligent Virtue (Oxford: Oxford University Press, 2013), p. 120). Daniel Haybron writes: "it is questionable whether any major school of philosophical thought denies outright the importance of happiness, at least on one of the plausible accounts of the matter." Daniel Haybron, "Happiness," The Stanford Encyclopedia of Philosophy, Fall 2011 Edition, Edward Zalta (ed.), http://plato.stanford.edu/archives/fall2011/entries/happiness/, Part 4.3. 2 For accounts of happiness, see Nicholas White, A Brief History of Happiness (Oxford: Blackwell, 2007); Annas, Intelligent Virtue, Ch. 8; Haybron, The Pursuit of Unhappiness: The Elusive Psychology of Well-Being (Oxford: Oxford University Press, 2010).

3 (1) unlike (3) allows partialist moral theories and agent-centered prerogatives. See Troy Jollimore, "Impartiality," The Stanford Encyclopedia of Philosophy, spring 2014 Edition, Edward Zalta (ed.), http://plato.stanford.edu/archives/spr2014/entries/impartiality. For (2), see John Lemos, "Morality, Self-Interest, and Two Kinds of Prudential Practical Rationality," Philosophia 34 (2006): 85-93, p. 86.

4 Cf. David Schmidtz, "Because it is Right," in Paul Bloomfield (ed.), Morality and SelfInterest (Oxford: Oxford University Press, 2008), 79-101, p. 84.

5 Cf. Beatrix Himmelmann and R. Louden (eds.), Why Be Moral? (Berlin: de Gruyter, 2015). 
6 See Ruth Chang (ed.), Incommensurability, Incomparability, and Practical Reason

(London: Harvard University Press, 1997) and John E. Hare, The Moral Gap: Kantian Ethics, Human Limits, and God's Assistance (Oxford: Clarendon, 2002).

7 Cf. Andrew Chignell, "The Ethics of Belief," The Stanford Encyclopedia of Philosophy, Spring 2013 Edition, Edward Zalta (ed.),

http://plato.stanford.edu/archives/spr2013/entries/ethics-belief.

8 The Stoics developed this position. See Christoph Horn, Antike Lebenskunst. Glück und Moral von Sokrates bis zu den Neuplatonikern (Munich: Beck, 1998), pp. 71ff., 85ff.

9 Cf. John E. Hare, God's Call: Moral Realism, God's Commands, and Human Autonomy (Grand Rapids: Eerdmans, 2001), pp. 43ff.; Hare, The Moral Gap, p. 93. I use the concept of injustice as shorthand for significant conflict between morality and prudence, and the concept of tragedy as shorthand for cases in which morality coincides with imprudence.

10 Aristotle, Nicomachean Ethics, 1153b 14-25, translated in Julia Annas, The Morality of Happiness (Oxford: Oxford University Press, 1995), p. 373.

11 See Susan Neiman, Evil in Modern Thought: An Alternative History of Philosophy (Princeton: Princeton University Press, 2004), p. 22.

12 See Annas, The Morality of Happiness, p. 40. This classical notion is controversial today. 13 See White, op. cit., pp. 45f., 100; Beatrix Himmelmann, Kants Begriff des Glücks (Berlin: de Gruyter, 2003), pp. 15ff., 184.

14 Cf. Annas, Intelligent Virtue, pp. 136f.

15 Jens Timmermann, "Divine Existence and Moral Motivation," in Stefano Bacin, Alfredo Ferrarin, Claudio La Rocca, and Margit Ruffing (eds.), Kant und die Philosophie in weltbürgerlicher Absicht, vols. 1-5 (Berlin: de Gruyter, 2013), vol. 3, 669-678, pp. 674f. 16 See Annas, The Morality of Happiness, Part 3; Horn, op. cit., Ch. 5. 17 See Plato, The Republic (New York: Basic, 1991), p. 39 (361b-c). 
18 See Immanuel Kant, Gesammelte Schriften, vols. 1-29 (Berlin: de Gruyter, 1900ff.), vol. 5, pp. 146f.; Frederick Beiser, "Moral Faith and the Highest Good," in Paul Guyer (ed.), The Cambridge Companion to Kant and Modern Philosophy (Cambridge: Cambridge University Press, 2006), 588-629, pp. 620-622; Neiman, op. cit., p. 68.

19 A closely related assumption is found in theories implying that free will involves choosing between alternative possibilities (e.g. self-interest and morality). Cf. Roe Fremstedal, Kierkegaard and Kant on Radical Evil and the Highest Good: Virtue, Happiness, and the Kingdom of God (Basingstoke: Palgrave Macmillan, 2014), Chs. 2-3.

20 See Horn, op. cit., p. 147 referencing Marcus Aurelius, Ad Se Ipsum, Book 8, para. 48. 21 See Samuel Scheffler, "Potential Congruence," in Bloomfield (ed.), op. cit., 117-135, pp. 118-120.

22 See John Silber, “The Importance of the Highest Good in Kant's Ethics,” Ethics 73 (1963): 179-197, p. 183.

23 For the view that virtue brings unhappiness, see Peter Wessel Zapffe, "Den sidste Messias," Janus 1 (1933): 645-656.

24 Cf. Annas, Intelligent Virtue, p. 167.

25 See Valerine Tiberius, Moral Psychology: A Contemporary Introduction (London: Routledge, 2013), pp. 179-184.

26 See Lemos, op. cit., p. 91 on Aristotle; Robert Stern, Understanding Moral Obligation: Kant, Hegel, Kierkegaard (Cambridge: Cambridge University Press, 2014), pp. 81ff. on Kant. 27 See C. Stephen Evans, "Moral Arguments for the Existence of God," The Stanford Encyclopedia of Philosophy, Summer 2014 Edition, Edward Zalta (ed.), http://plato.stanford.edu/archives/sum2014/entries/moral-arguments-god. 28 See Francesco Orsi, “The Dualism of the Practical Reason: Some Interpretations and Responses," Etica \& Politica / Ethics \& Politics 10 (2008): no. 2: 19-41. 
29 See Mathias Sagdahl, “The Argument from Nominal-Notable Comparisons, 'Ought All Things Considered', and Normative Pluralism," The Journal of Ethics 18 (2014): 405-425, pp. 405ff.; Chang (ed.), op. cit.

30 See White op. cit., pp. 119, 138; Orsi, op. cit.

31 Kant, op. cit., vol. 29, pp. 777f.

32 Kant, op. cit., vol. 5, pp. 111f., 127.

33 See Jacqueline Marina, "Making Sense of Kant's Highest Good,” Kant-Studien 91 (2000): 329-355. See also Himmelmann, op. cit., Ch. 6.

34 Kant, op. cit., vol. 29, p. 777.

35 Kant, op. cit., vol. 28, p. 1151.

36 For the objectivist view, see Haybron, The Pursuit of Unhappiness, p. 187. For the psychological claim that we all desire our own happiness, see Evans, op. cit.

37 See Robert Adams, The Virtue of Faith and Other Essays in Philosophical Theology (Oxford: Oxford University Press, 1987), pp. 151ff. Kant (op. cit., vol. 4, p. 399) argues that attaining personal happiness is an indirect moral duty, since personal unhappiness can contribute to a transgression of one's moral duties.

38 See Viktor Frankl, Man's Search for Meaning (London: Rider, 2004), pp. 19, 60, 76, 99. 39 See Orsi, op. cit.; White, op. cit., p. 119.

40 Terence Irwin, The Development of Ethics: A Historical and Critical Study, vols. 1-3 (Oxford: Oxford University Press, 2011), vol. 2, p. 549.

41 See Søren Kierkegaard, Fear and Trembling (Princeton: Princeton University Press, 1983), pp. 27, 63.

42 See Kant, op. cit., vol. 4, p. 394.

43 See Tiberius, op. cit., Ch. 10.

44 Ibid., pp. 178, 182, 179 respectively. 
45 Daniel Haybron, Happiness: A Very Short Introduction (Oxford: Oxford University Press, 2013), p. 62.

46 See Sagdahl, op. cit., pp. 413-416; Lemos, op. cit.

47 See Lemos, op. cit., p. 91; Stern, op. cit.

48 Sagdahl, op. cit., p. 416.

49 For a partial reconstruction and defense, see, e.g., Antony Rudd, Self, Value and Narrative: A Kierkegaardian Approach (Oxford: Oxford University Press, 2012). Lemos (op. cit., p. 90) criticizes the Platonic notion of psychic harmony, and by extension AugustinianKierkegaardian notions of spiritual death and despair, by claiming that immoral persons may feel happy. Still, this need not imply that they are truly happy or prudentially rational. 50 Lemos, op. cit., p. 90.

51 Ibid., pp. 91f.

52 See ibid. See also Sagdahl, op. cit., pp. 415f.; Scheffler, op. cit., p. 119.

53 See Irwin, op. cit.; Annas, The Morality of Happiness and Intelligent Virtue; Horn, op. cit. Rudd (op. cit., Part 1) defends virtues and characters against situationism. He argues that activities and projects with meaning and significance involve final ends that we care about for their own sake. Such activities and projects involves sustaining relationships and taking part in social practices that come with standards of assessment that are intersubjective, noninstrumental, and moral. See also Himmelmann and Louden (eds.), op. cit., Part 2. 54 See Christoph Horn, Nichtideale Normativität. Ein neuer Blick auf Kants politische Philosophie (Frankfurt am Main: Suhrkamp, 2014), p. 251; Pauline Kleingeld, Kant and Cosmopolitanism: The Philosophical Ideal of World Citizenship (Cambridge: Cambridge University Press, 2012), p. 175. See also Fremstedal, op. cit., pp. 92f., 186f. 55 Robert Louden, “General Introduction," in Immanuel Kant, Anthropology, History, and Education (Cambridge: Cambridge University Press, 2007), 1-17, p. 13. 
56 See Fremstedal, op.cit., Chs. 4-9. See also Kleingeld, op. cit.; Horn, op. cit., Ch. 5.

57 See Haybron, The Pursuit of Unhappiness, pp. 163f.

58 For dystopic scenarios involving exceptional conflict between morality and prudence, see

C. Stephen Layman, "God and the Moral Order," Faith and Philosophy 19 (2002): 304-316.

59 See Robert Shaver, "Egoism,” The Stanford Encyclopedia of Philosophy, Spring 2015

Edition, Edward Zalta. (ed.), http://plato.stanford.edu/archives/spr2015/entries/egoism.

60 Irwin, op. cit., vol. 1, p. 289.

61 Ibid.

62 Justin Clark, "Eudaimonistic Virtue Ethics and Self-Effacement," Journal of Value Inquiry 50 (2016): 507-524.

63 For a discussion focusing on Socrates and Jesus, see, e.g., Georg Kateb, "Morality and Self-Sacrifice, Martyrdom and Self-Denial," Social Research 75 (2008): 353-394.

64 See Lemos, op. cit., p. 88.

65 See Rudd, op. cit. See also Himmelmann and Louden (eds.), op. cit., Part 2.

66 For additional support of this view, see Alessio Vaccari, "Prudence and Morality in Butler, Sidgwick, and Parfit,” Etica \& Politica / Ethics \& Politics 10 (2008), no. 2: 72-108.

67 Cf. Hare, The Moral Gap, p. 86.

68 Cf. ibid. p. 86.

69 See Evans, op. cit.; Adams, op. cit.; Hare, The Moral Gap; Beiser, op. cit.; Jordan, op. cit. 70 See Evans, op. cit.; Adams, op. cit., pp. 144ff.; Beiser, op. cit.; Chignell, op. cit. 71 See Hare, The Moral Gap; Beiser, op. cit.

72 See Adams, op. cit., pp. 144ff.; Hare, God's Call, pp. 86ff.; Hare, The Moral Gap, pp. 95f. 73 Thanks to the anonymous reviews, Jonathan Beale, and Robert Shaver, as well as audiences in Bonn, Troms $\emptyset$, and Trondheim, for comments on earlier versions of this text. 